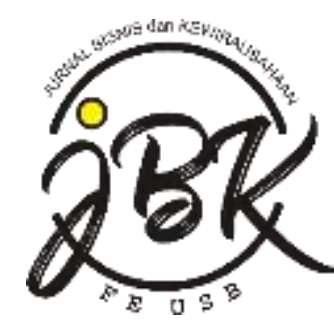

\title{
PERAN MEDIASI RENCANA BEROBAT DAN MODERASI KONTROL KEPERILAKUAN AKTUAL DAN KONTEKS SITUASIONAL DALAM HUBUNGAN ANTARA NIAT BEROBAT DAN KEPUTUSAN BEROBAT
}

\author{
Andika Anang Winarso ${ }^{1}$ \\ Universitas Setia Budi Surakarta \\ (andika.anang16@gmail.com) \\ Waluyo Budi Atmoko² \\ Universitas Setia Budi Surakarta \\ (waluyobudiatmoko@gmail.com) \\ Finisha Mahaestri Noor ${ }^{3}$ \\ Universitas Setia Budi Surakarta \\ (finisha_noor@yahoo.com)
}

\begin{abstract}
This study aims to examine the mediating role of the implementation plan in the relationship between medical intention and treatment decisions, examine the role of moderation of actual behavioral control in the relationship between implementation plans and treatment decisions, and examine the role of situational context moderation in the relationship between treatment plans and treatment decisions. The decision to treat a patient is important for the hospital because it determines the number of patients who will seek treatment at the hospital. Data obtained through questionnaires distributed to patient or someone who want to be a patient. The research sample used amounted 200. This research use purposive sampling in Solo Raya. Hypothesis testing used regression logistic for mediating and moderating role. First hypothesis are supported but second and third hypothesis was not supported.
\end{abstract}

KEYWORD: Treatment intentions, treatment plans, treatment decisions, actual behavioral control, situational context

\section{A. PENDAHULUAN}

Keputusan berobat sangat penting bagi rumah sakit, karena merupakan kepastian dari pasien untuk mengonsumsi jasa perawatan kesehatan yang disediakan oleh rumah sakit. Keputusan berobat terjadi mengikuti proses pengambilan keputusan pembelian konsumen. Kotler dan Keller (2016) menyatakan, proses pengambilan keputusan pembelian konsumen mengikuti proses yang terdiri dari lima tahap: (1) pengakuan adanya masalah, (2) pencarian informasi, (3) evaluasi alternative, (4) keputusan pembelian, dan (5) evaluasi pascabeli. alternative, (4) keputusan pembelian, dan (5) evaluasi pascabeli.

Tahap keputusan beli, sebelum konsumen memutuskan membeli suatu barang atau jasa, konsumen telah membentuk niat beli. Umumnya seseorang yang telah meniatkan suatu tindakan, akan melakukan tindakan yang diniatkannya. Niat 
Jurnal Bisnis dan Kewirausahaan

beli tidak selalu memprediksi perilaku/keputusan beli dalam sejumlah ranah perilaku (Carington et al., 2010; Chatzidakis, 2014). Tahapan paling krusial pada pembentukan keputusan beli adalah terletak pada perubahan antara niat beli dan keputusan beli. Ketidakkonsistenen perubahan niat menjadi perilaku/keputusan ini juga terjadi dalam ranah industri pelayanan kesehatan. Seseorang yang berniat berobat belum tentu melaksanakan niatnya untuk berobat di rumah sakit yang diniatkannya. Oleh karena itu, pengelola rumah sakit harus mengeksplorasi faktorfaktor yang menjamin niat untuk berobat menjadi keputusan berobat.

Studi berhasil mengidentifikasi kesenjangan penelitian, yaitu niat berobat yang sudah terbentuk belum tentu mewujud dalam keputusan berobat (Carrington et al., 2010; Kotler dan Keller, 2016). Kotler dan Keller (2016) menyatakan bahwa antara niat beli dan keputusan beli terdapat faktor: sikap orang lain dan situasi tidak terantisipasi. Berbeda dari Kotler dan Keller (2016), Carrington et al. (2010) dalam studinya mengusulkan konstruk pengisi kesenjangan antara niat dan perilaku, yaitu: niat pelaksanaan, kontrol keperilakuan aktual, dan konteks situasional. Niat pelaksanaan dikonseptualisasikan memediasi hubungan antara niat dan perilaku. Secara logika, seseorang yang meniatkan suatu tindakan, tentu akan menyusun rencana pelaksanaan. Rencana pelaksanaan ini yang akan
Vol-13/No-2/Oktober/2020

memandu niat sehingga berbuah menjadi perilaku.

Kontrol keperilakuan aktual dimaknai sebagai persepsi individu seberapa jauh dari kenyataan saat membayangkan situasi baru atau sesuatu dimana individu mempunyai sedikit pengalaman dengannya (Ajzen, 1991; Notani, 1998; Morwitz et al., 2007). Kontrol keperilakuan aktual berbeda dengan kontrol keperilakuan persepsian. Kontrol keperilakuan persepsian merujuk pada persepsi seseorang tentang kemampuannya melakukan suatu perilaku (Carrington et al., 2010). Konteks situasional merujuk pada kombinasi faktor internal dan eksternal dari individu. Faktor situasional mencakup: lingkungan fisis, lingkungan sosial, waktu, definisi tugas, state anteseden (kekuatiran, kegairahan, kejujuran), dan keterbatasan sesaat (keberadaan uang di saku, kelelahan, kesakitan).

\section{B. TELAAH LITERATUR}

\section{Keputusan Berobat}

Keputusan pembelian dibuat ketika seseorang menyadari suatu masalah atau kebutuhan yang dipicu oleh rangsangan internal dan rangsangan eksternal. Konsumen akan melakukan pencarian informasi dalam upaya memenuhi kebutuhannya. Proses pencarian informasi akan mengarahkan pada sejumlah alternatif produk atau merek. Konsumen memiliki lima subkeputusan dalam melaksanakan maksud pembelian yaitu merek, dealer, kuantitas, 
waktu, dan metode pembayaran (Kotler dan Keller, 2016). Tahapan keputusan pembelian tidak berhenti setelah konsumen memutuskan pembelian, namun ada tahapan perilaku pasca pembelian. Setelah pembelian produk terjadi, konsumen akan mengalami suatu tingkat kepuasan atau ketidakpuasan. Kepuasan atau ketidakpuasan konsumen terhadap produk akan memengaruhi perilaku konsumen berikutnya.

Atas dasar uraian di atas, maka keputusan didefinisikan sebagai proses menentukan suatu pilihan dengan memilih kondisi lebih baik atau lebih menguntungkan (Elwyn, 2009). Dalam literatur kesehatan keputusan berobat didefinisikan sebagai sebuah proses interaktif antara dokter dan pasien dalam semua tahapan proses pengambilan keputusan dan bersama sama bernegosiasi untuk melaksanakan pengobatan (Charles et al. 2003). Maka keputusan berobat dapat didefinisikan sebagai pemecahan masalah kesehatan dengan memilih rumah sakit atas dasar pertimbangan kondisi lebih baik dan menguntungkan (Elwyn, 2009; Kotler dan Keller, 2016).

\section{Niat Berobat}

Dharmmesta (1998) menyatakan: pertama, niat dianggap sebagai penangkap atau perantara faktor faktor motivasional yang mempunyai dampak pada suatu perilaku. Kedua, niat menunjukkan seberapa keras seseorang berani mencoba. Ketiga, niat juga menunjukkan seberapa banyak upaya yang direncanakan seseorang untuk dilakukan, dan. Keempat, niat adalah paling dekat berhubungan dengan perilaku selanjutnya. Niat adalah konstruk paling dekat berhubungan dengan perilaku. Sheeran dan Webb (2016) mendefinisikan niat keperilakuan sebagai perintah diri (selfinstructions) untuk melakukan tindakan tertentu searah dengan pencapaian hasil.

Atas dasar beberapa definisi tersebut, maka niat keperilakuan didefinisikan sebagai upaya yang direncanakan untuk melakukan tindakan tertentu (Dharmmesta, 1998; Sheeran dan Webb, 2016). Niat dalam konteks perawatan kesehatan, niat keperilakuan dimaknai sebagai niat berobat dan didefinisikan sebagai upaya yang direncanakan untuk memilih tempat berobat/rumah sakit (Dharmmesta, 1998; Sheeran dan Webb, 2016). Soderlund dan Ohman (2005) menyatakan bahwa niat dapat digambarkan dalam tiga bentuk: (1) niat sebagai rencana, (2) niat sebagai keinginan, dan (3) niat sebagai harapan. Ketiga bentuk niat dapat dianggap sebagai dimensi dari niat keperilakuan.

Carrington et al. (2010) menyatakan bahwa pada umumnya, segera setelah niat terbentuk, maka dibuat rencana pelaksanaan atau niat pelaksanaan. Oleh karena itu sebetulnya, antara niat dan perilaku terdapat konstruk perantara yaitu rencana pelaksanaan. Rencana pelaksanaan dalam 
konteks penelitian ini adalah rencana berobat di rumah sakit.

\section{Rencana Berobat}

Rencana pelaksanaan merujuk pada waktu, tempat, dan bagaimana mewujudkan niat tersebut (Carrington et al., 2010). Penyusunan rencana pelaksanaan akan menghindarkan ketidakpuasan terhadap keputusan yang diambil. Rencana pelaksanaan dalam konteks penelitian ini dapat dimaknai sebagai rencana berobat di rumah sakit. Atas dasar penjelasan di atas, maka rencana berobat dapat didefinisikan sebagai rencana waktu, pilihan rumah sakit, dan bagaimana melaksanakan pengobatan (Carrington et al., 2010).

Atas dasar peran rencana pelaksanaan dalam memandu perhatian individu pada situasi dan peluang terjadinya perilaku, maka Carrington et al., (2010) menyatakan bahwa rencana pelaksanaan memediasi hubungan antara niat dan perilaku menyatakan ada tiga dimensi penting dalam upaya mengukur konstruk. Peran mediator rencana pelaksanaan dalam hubungan antara niat dan perilaku ini dikonfirmasi dalam penelitian Hassan et al. (2014) dan Grimmer dan Mills (2017). Hassan et al. (2014) dalam penelitiannya pada industri industri pakaian murah, berhasil mengonfirmasi peran mediasi rencana pelaksanaan dalam hubungan antara niat dan perilaku beli. Grimmer dan Mills (2017) dalam penelitiannya pada produk ramah lingkungan juga mendapati bahwa rencana penelitian memediasi hubungan antara niat dan perilaku beli. Atas dasar deskripsi tersebut, maka dapat diajukan hipotesis:

$\mathrm{H}_{1}$ : Rencana berobat ke rumah sakit memediasi hubungan antara niat berobat dan keputusan berobat.

\section{Kontrol Keperilakuan Aktual}

Kontrol keperilakuan aktual didefinisikan sebagai persepsi individu seberapa jauh dari kenyataan saat membayangkan situasi baru atau sesuatu dimana individu mempunyai sedikit pengalaman dengannya (Ajzen, 1991; Notani, 1998; Morwitz et al., 2007). Kontrol keperilakuan aktual berbeda dengan kontrol keperilakuan persepsian. Kontrol keperilakuan persepsian merujuk pada persepsi seseorang tentang kemampuannya melakukan suatu perilaku (Carrington et al., 2010).

Ajzen (2002) menyatakan bahwa pengukuran kontrol keperilakuan didasarkan pada pendekatan: berbasis keyakinan dan langsung. Pengukuran berbasis keyakinan dilakukan dengan mengidentifikasi keyakinan kontrol yang menghambat pelaksanaan suatu perilaku (Carrington et al., 2010). Hassan et al. (2014) mengukur kontrol keperilakuan aktual atas dasar tingkat kesulitan persepsian individu dalam menjalankan suatu perilaku. Tingkat kesulitan dalam menjalankan perilaku ini jelas mempengaruhi apakah suatu perilaku 
akan terlaksana atau tidak. Persepsi mudah bagi individu dalam mewujudkan perilaku, memperbesar probabilitas suatu perilaku direalisasikan. Dalam konteks pelayanan kesehatan, persepsi sulit/mudahnya berobat di suatu rumah sakit akan memperkuat/memperlemah keputusan berobat di rumah sakit yang diniatkan. Oleh karena itu, dapat diajukan hipotesis:

$\mathrm{H}_{2}$ : kontrol keperilakuan aktual memoderasi secara positif hubungan antara niat berobat dan keputusan berobat di rumah sakit.

\section{Konteks Situasional}

Konteks situasional merujuk pada kombinasi faktor internal dan eksternal dari individu. Faktor situasional mencakup: lingkungan fisis, lingkungan sosial, waktu, definisi tugas, state anteseden (kekuatiran, kegairahan, kejujuran), dan keterbatasan sesaat (keberadaan uang di saku, kelelahan, kesakitan). Belk (1975) menyarankan taksonomi dari lima faktor situasional menyeluruh yang mendefinisikan konteks situasional. Taksonomi ini didasarkan pada kombinasi faktor situasional internal dan eksternal individu. Faktor situasional tersebut adalah: pertama, lingkungan fisik yaitu penempatan dan visibilitas produk, kedekatan produk dan akses ke perbandingan harga. Kedua, lingkungan sosial yaitu kehadiran orang lain, peran mereka, dan interaksi interpersonal yang terjadi. Ketiga, perspektif temporal yaitu semua aspek terkait waktu dari situasi, misal: waktu, waktu pembatasan, waktu sejak pembelian terakhir. Keempat, definisi tugas yaitu tujuan individu dalam situasi tersebut, misal: pertimbangkan apakah individu berniat untuk memilih, membeli atau mengumpulkan informasi tentang membeli, dan tugas dapat dipertimbangkan apakah pembeli juga merupakan pengguna akhir. Kelima, anteseden sesaat yaitu: menyatakan saat individu membawa (anteseden) ke situasi, dan termasuk suasana hati sesaat (seperti kecemasan, permusuhan, eksitasi) dan kendala sesaat (seperti uang tunai, kelelahan, sakit).

$$
\text { Kotler dan Keller (2016 h.199) }
$$

menyatakan bahwa faktor situasi tak terantisipasi berperan memperkuat atau memperlemah hubungan antara niat membeli dan keputusan pembelian. Faktor konteks situasional dalam proposisinya pada pembelian produk etis memoderasi hubungan antara rencana pelaksanaan dan perilaku, dimana rencana pelaksanaan berperan sebagai moderator hubungan antara niat dan perilaku (Carrington et al., 2010; Hassan et al., 2014; Grimmer dan Mills, 2017 ). Berdasarkan uraian ini, maka dapat diajukan hipotesis:

$\mathrm{H}_{3}$ : faktor konteks situasional memoderasi secara positif hubungan antara niat berobat dan keputusan berobat di rumah sakit 


\section{Model Penelitian}

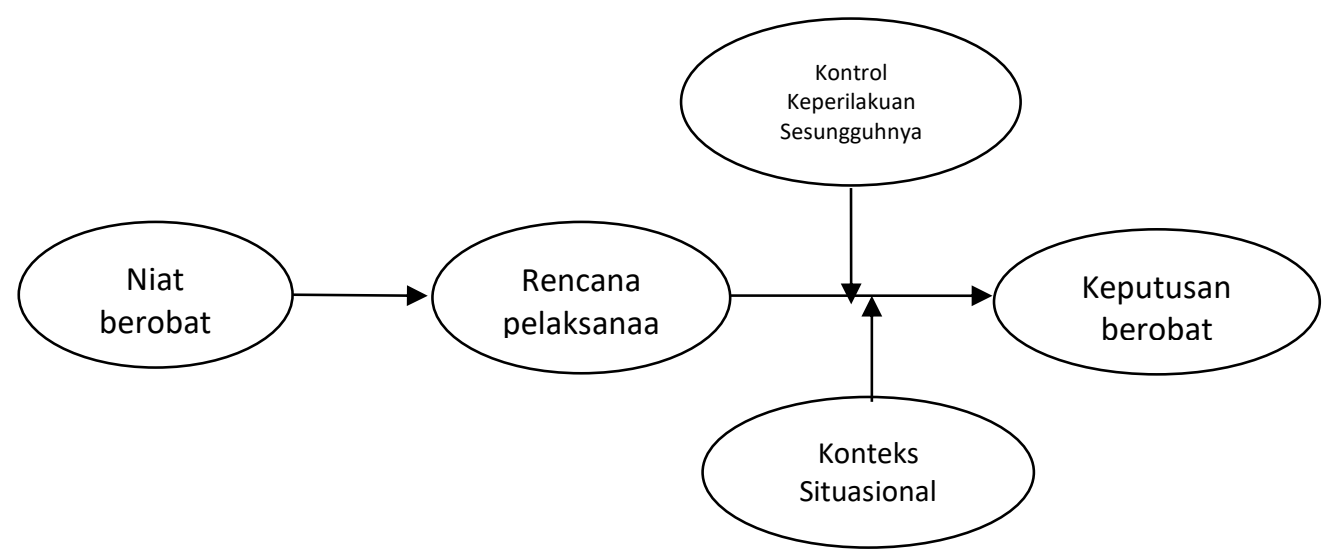

Gambar 1. Model Penelitian

\section{METODE PENELITIAN}

Penelitian ini bersifat Cross Sectional dengan teknik survei dalam bentuk kuisioner dalam pengambilan data. Teknik penyampelan menggunakan purposive sampling dengan jumlah sampel sebanyak 200 responden yang merupakan pasien ataupun calon pasien di Rumah Sakit yang berada di wilayah Kota Surakarta. Pengujian alat ukur dalam penelitian ini menggunakan uji validitas dan uji reliabilitas dengan program SPSS. Pengujian Hipotesis menggunakan Analisis Regresi Logistik
Mediasi dan Regresi Logistik Moderasi menggunakan program SPSS.

\section{Pengujian Alat Ukur}

Hasil pengujian validitas kuesioner menunjukkan bahwa 11 pernyataan yang diajukan menggunakan skala likert dalam penelitian ini valid dan terletak pada faktor yang sama dalam uji validitas. Pengujian reliabilitas untuk masing masing variabel memiliki nilai lebih besar dari 0,6. Sehingga dapat bahwa dimaknai semua item kuesioner reliabel dan dapat digunakan untuk pengambilan data

\begin{tabular}{cccc}
\hline Butir Kuesioner & $\begin{array}{c}\text { Loading Factor } \\
\text { Minimal= } \mathbf{0 , 5}\end{array}$ & Nilai Cronbach Alpha & Keterangan \\
\hline NB1 & 0,868 & 0,805 & Valid dan Reliabel \\
NB2 & 0,769 & & Valid dan Reliabel \\
NB3 & 0,850 & \multirow{2}{*}{0,792} & Valid dan Reliabel \\
RB1 & 0,872 & & Valid dan Reliabel \\
RB2 & 0,786 & & Valid dan Reliabel \\
RB3 & 0,809 & 0,872 & Valid dan Reliabel \\
KS1 & 0,884 & & Valid dan Reliabel \\
KS2 & 0,832 & Valid dan Reliabel \\
KS3 & 0,766 & & Valid dan Reliabel \\
KS4 & 0,736 & Valid dan Reliabel \\
KS5 & 0,780 & & Valid dan Reliabel \\
\hline
\end{tabular}

Tabel 1. Hasil Uji Validitas dan Reliabilitas 


\section{HASIL ANALISIS}

Hasil pengujian menggunakan analisis regresi logistik mediasi dan moderasi. Hasil analisis akan ditampilkan pada tabel 2 . Hasilnya menunjukkan bahwa rencana berobat merupakan mediasi dari niat berobat dan keputusan berobat. Rencana berobat memediasi penuh variabel niat berobat dan keputusan berobat. Hasil dari hubungan antara niat berobat dan keputusan berobat dimoderasi oleh kontrol keperilakuan aktual ditampilkan pada tabel 3. Hasil dari hubungan antara niat berobat pasien dan keputusan berobat yang dimoderasi oleh konteks situasinoal ditampilkan pada tabel 4.

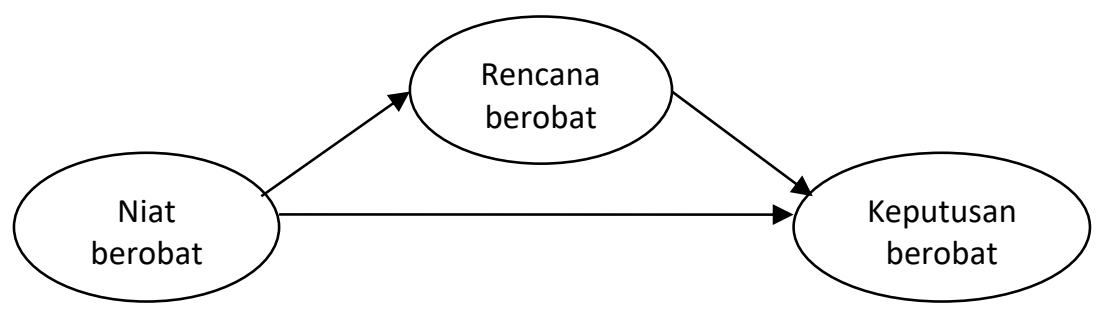

Gambar 2. Regresi Variabel Keputusan Berobat dengan mediasi Rencana Berobat

Persamaan 1 (Regresi Logistik NB $\rightarrow$ KB

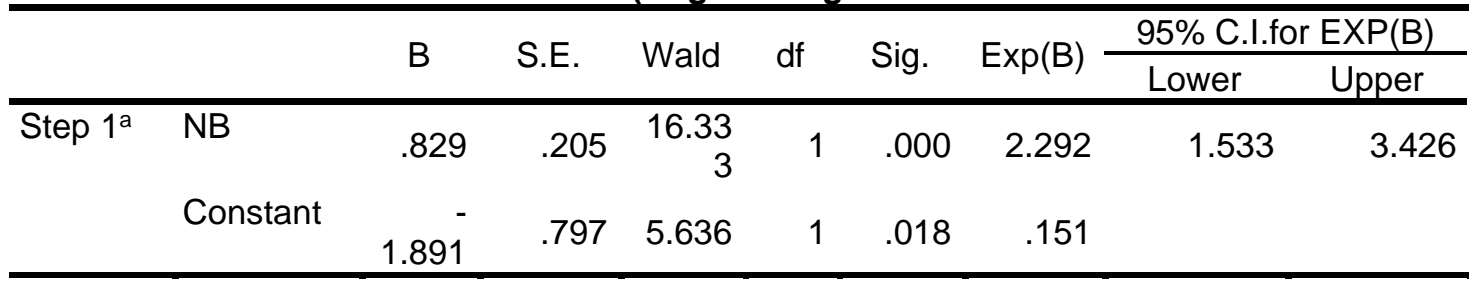

a. Variable(s) entered on step 1: NB.

Persamaan 3 (Regresi Logistik Mediasi)

\begin{tabular}{llrrrrrrrrr}
\hline & & \multicolumn{1}{c}{ B } & S.E. & Wald & df & Sig. & Exp(B) & \multicolumn{2}{c}{ 95\% C.I.for EXP(B) } \\
\hline Step 1a & NB & .224 & .246 & .829 & 1 & .363 & 1.251 & .773 & 2.024 \\
& RB & 1.270 & .229 & 30.63 & 1 & .000 & 3.560 & 2.271 & 5.582 \\
& & & 1 & & & & & \\
& Constant & -3.671 & .952 & 14.87 & & 1 & .000 & .025 & & \\
\hline
\end{tabular}

a. Variable(s) entered on step 1: NB, RB.

Tabel 2. Hasil Analisis Regresi Logistik Mediasi 


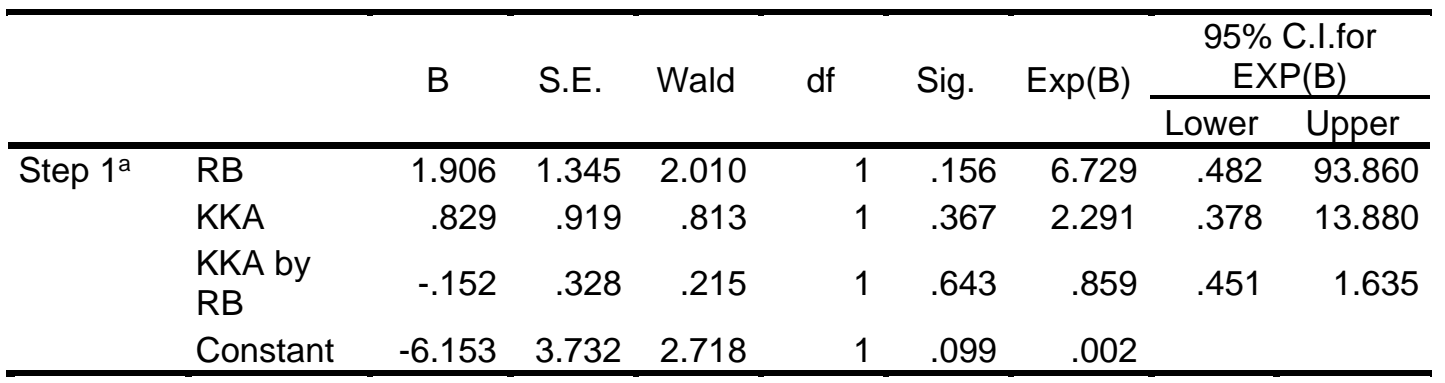

a. Variable(s) entered on step 1: RB, KKA, KKA * RB .

Tabel 3. Hasil Analisis Regresi Logistik Moderasi Kontrol Keperilakuan Aktual Variables in the Equation

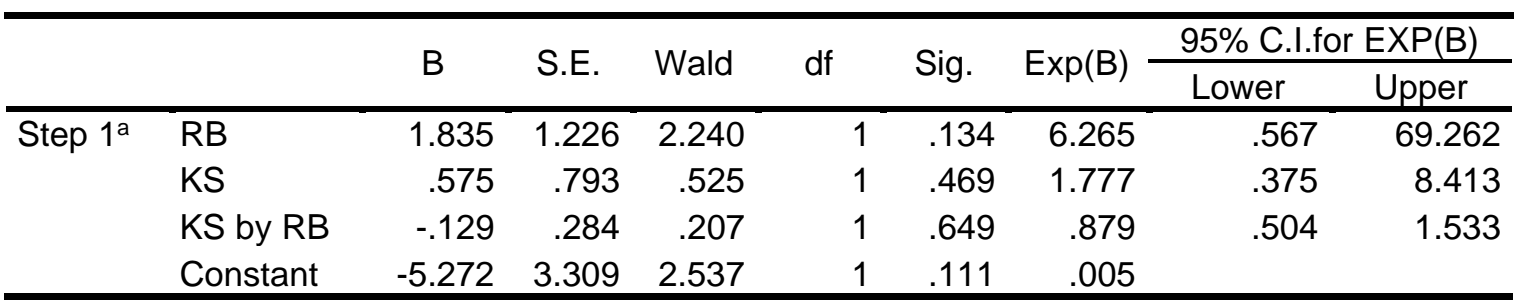

a. Variable(s) entered on step 1: RB, KS, KS * RB .

Tabel 4. Hasil Analisis Regresi Logistik Moderasi Konteks Situasional Variables in the Equation

\section{E. PEMBAHASAN}

Hasil uji hipotesis pertama penelitian ini terdukung dengan menjelaskan bahwa rencana pelaksanaan berobat merupakan mediasi penuh pada variabel antara niat berobat dan keputusan berobat. Hal ini sejalan dengan penelitian yang telah dilakukan Carrington et al. (2010) yang menyatakan bahwa rencana pelaksanaan memediasi hubungan antara niat dan perilaku. Hassan et al. (2014) dalam penelitiannya pada industri industri pakaian murah, berhasil mengonfirmasi peran mediasi rencana pelaksanaan dalam hubungan antara niat dan perilaku beli. Grimmer dan Mills (2017) dalam penelitiannya pada produk ramah lingkungan juga mendapati bahwa rencana penelitian memediasi hubungan antara niat dan perilaku beli. Maka ketika seseorang berniat untuk melakukan pengobatan, akan mempertimbangkan rencana dalam pelaksanaan berobat tersebut dan pada akhirnya akan dilakukan keputusan berobat. Baik sesorang nantinya memutuskan untuk berobat ataupun tidak.

Hasil Uji hipotesis kedua penelitian ini tidak terdukung. Karena hasilnya kontrol keperilakuan aktual bukan lah variabel moderator dalam hubungan antara variabel rencana pelaksanaan berobat dengan keputusan berobat. Variabel kontrol keperilakuan dimaknai sebagai variabel bebas dan bukan merupakan variabel moderator $\mathrm{Hal}$ tidak sejalan dengan penelitian yang telah dilakukan oleh 
Carrington et al. (2010) yang menyatakan bahwa keyakinan kontrol akan menghambat pelaksanaan pada niat dalam perilaku atau keputusan.

Hasil uji hipotesis yang ketiga dalam penelitian ini juga tidak terdukung. Hasilnya memperlihatkan bahwa konteks situasional bukanlah sebagai variabel moderator dalam hubungan antara rencana pelaksanaan dan keputusan berobat. Hasil ini dimaknai bahwa konteks situasional merupakan variabel bebas dan bukan variabel moderator. Penelitian ini tidak sejalan dengan penelitian yang telah dilakukan sebelumnya yang menyatakan Faktor konteks situasional dalam proposisinya pada pembelian produk etis memoderasi hubungan antara rencana pelaksanaan dan perilaku, dimana rencana pelaksanaan berperan sebagai moderator hubungan antara niat dan perilaku (Carrington et al., 2010; Hassan et al., 2014; Grimmer dan Mills, 2017).

\section{F. KESIMPULAN}

Penelitian ini mendapatkan kesimpulan pertama bahwa dalam mengidentifikasi pengaruh rencana pelaksanaan pada variabel antara niat berobat dan keputusan berobat yaitu variabel rencana pelaksanaan berobat memediasi penuh variabel niat berobat dan keputusan berobat. Kesimpulan kedua bahwa kontrol keperilakua aktual bukan meripakan variabel moderasi dalam hubungan antara rencana pelaksanaan berobat dan keputusan berobat. kontrol keperilakuan merupakan variabel bebas. Kesimpulan ketiga bahwa konteks situasional bukanlah sebagai variabel moderator dalam hubungan antara rencana pelaksanaan berobat dan keputusan berobat. hasilnya adalah konteks situasional merupakan variabel bebas.

\section{Implikasi Manajerial}

Hasil penelitian menghasilkan bahwa rencana pelaksanaan memediasi antara niat dan keputusan berobat calon pasien atau pasien. Hal ini menandakan, rumah sakit bisa menyediakan wadah untuk pasien atau calon pasien untuk melakukan perencanaan pelaksanaan berobatnya. $\mathrm{Hal}$ ini bisa didukung dengan rumah sakit yang memberikan pelayanan aplikasi atau pendaftaran secara daring untuk mendukung perencanaan yang dilakukan oleh pasien atau calon pasien.

\section{REFERENSI}

Aaker, D. A. (1992). The Value of Brand Equity. Journal of Business Strategy, 13(4), pp. 27-32. doi: 10.1108/eb039503.

Aaker, D. A. (1994). Building a Brand: The Saturn Story'.

Aaker, J. L. (1997). Dimensions of brand personality.Journal of Marketing Research, 34(3), pp. 347-356. doi: $10.2307 / 3151897$.

Alrubaiee, L. S. et al. (2017). Relationship between Corporate Social 
Responsibility and Marketing

Performance: The Mediating Effect of

Customer Value and Corporate Image.International Business

Research, 10(2), p. 104. doi: 10.5539/ibr.v10n2p104.

Ajzen, I. (1991). The theory of planned behavior. Organizational Decision and Human Decision Process, 50, pp.179-211.

Ajzen, I. (2002). Perceived behavioral control, self-efficacy, locus of control, and the theory of planned behavior. Journal of Applied Social Psychology, 32(4), 665-683.

Baker, J. and Ozaki, R. (2008). Proenvironmental products: Marketing influence on consumer purchase decision.Journal of Consumer Marketing, 25(5), pp. 281-293. doi: 10.1108/07363760810890516.

Barich, H. and Koder, P. (1991). A Framework for Marketing Image Management'.

Belk, R. W. (1975). Situational Variables and Consumer Behavior.Journal of Consumer Research, 2(3), p. 157. doi: 10.1086/208627.

Berens, G. and van Riel, C. B. M. (2004). Corporate Associations in the Academic Literature: Three Main Streams of Thought in the Reputation Measurement Literature.Corporate Reputation Review, 7(2), pp. 161178.

doi: 10.1057/palgrave.crr.1540218.

Bohner, G. and Dickel, N. (2011). Attitudes and Attitude Change Moral Foundations and Social Perception of Sexual Violence: a Cross-Cultural Research View Project Audience Tuning and Saying is Believing View Project.Article in Annual Review of Psychology, 62(January), pp. 391417.

doi: 10.1146/annurev.psych.121208.131 609.

Carrington, M. J., Neville, B. A. and Whitwell, G. J. (2010). Why ethical consumers don't walk their talk: Towards a framework for understanding the gap between the ethical purchase intentions and actual buying behaviour of ethically minded consumers.Journal of Business Ethics, 97(1), pp. 139-158. doi: 10.1007/s10551-010-0501-6.

Carroll, A. B. (1991). The Pyramid of Corporate Social Responsibility: Toward the Moral Management of Organizational

Stakeholders.Munchener medizinische Wochenschrift (1950), 112(44), pp. 2011-6. Available at: http://www.ncbi.nlm.nih.gov/pubmed 15536871.

Charles, C. A. et al. (2003). Shared treatment decision making: What does it mean to physicians?.Journal of Clinical Oncology, 21(5), pp. 932-936. doi: 
10.1200/JCO.2003.05.057.

Chatzidakis, Andreas. 2014. "Athens as a Failed City for Consumption." In Crisis-Scapes: Athens and Beyond, edited by Jaya Brekke, Dimitris Dalakoglou, Christos Filippides, and Antonis Vradis, 3341. Athens: Synthesi.

Cretu, A. E. and Brodie, R. J. (2005). The influence of brand image and company reputation where manufacturers market to small firms: A customer value perspective.Industrial Marketing Management, 36(2), pp. 230-240. doi:

10.1016/j.indmarman.2005.08.013.

Dharmmesta, B. D. (1998). "Theory Of Planned Behavior dalam Penelitian Sikap, Niat dan Perilaku Konsumen". Kelola, pp. 85-163.

Elwyn, G. and Miron-Shatz, T. (2009). Deliberation before determination: The definition and evaluation of good decision making. Health Expectations, 13(2), pp. 139-147. doi: 10.1111/j.13697625.2009.00572.x.

Grimmer M and Miles M. 2017. With the best of intentions: a large sample test of the intention-behaviour gap in proenvironmental consumer behaviour. International Journal of Consumer Studies 41:2-10.
Hair, J. F., Black, W.C., Babin, B.J., \& Anderson, R. E (2010). Multivarite Date Analysis. Sevent edition, New York : Hall International Inc.

Hagtvedt, H. and Patrick, V. M. (2009). The broad embrace of luxury: Hedonic potential as a driver of brand extendibility.Journal of Consumer Psychology. Society for Consumer Psychology, 19(4), pp. 608-618. doi: 10.1016/j.jcps.2009.05.007.

Hassan, L. M., Shiu, E., \& Shaw, D. (2014). Who says there is an intention-behaviour gap? Assessing the empirical evidence of an intention-behaviour gap in ethical consumption. Journal of Business Ethics, 136(2), 1-18. doi:10.1007/s10551-014-2440-0

Helm, S. (2005). Designing a Formative Measure for Corporate Reputation.Corporate Reputation Review, 8(2), pp. 95-109. doi: 10.1057/palgrave.crr.1540242.

Idowu, S. O. and Papasolomou, I. (2007). Are the corporate social responsibility matters based on good intentions or false pretences? An empirical study of the motivations behind the issuing of CSR reports by UK companies.Corporate Governance, 7(2), pp. 136-147. doi: 10.1108/14720700710739787.

Katz, D. (1960). The Functional Approach to the Study of Attitudes. Public Opinion 


\section{Vol-13/No-2/Oktober/2020}

Quarterly, 24(2, Special Issue: Attitude Change), p. 163. doi: 10.1086/266945.

Kim, K. H. et al. (2011). Effective employment brand equity through sustainable competitive advantage, marketing strategy, and corporate image.Journal of Business Research. Elsevier B.V., 65(11), pp. 1612-1617. doi: 10.1016/j.jbusres.2011.02.047.

Kotler, Philip. (2003). Marketing Insights from A to Z. Canada: John Wiley \& Sons, Inc.

Kotler, Philip., Keller, L., K., 2006. 5th edition. Marketing management. New Jersey: Prentice hall.

Kotler, Philip \& Kevin L. Keller. (2009). Manajemen pemasaran jilid 1, edisi Ketiga belas, Terjemahan Bob Sabran. Jakarta: Erlangga.

Kotler, Philip; Keller, K.L. (2016). Marketing Management. Global Edition. America: Pearson Education, Inc.

Lapiere, R. T. (1936). Type-Rationalizations of Group Antipathy.Social Forces, 15(2), pp. 232-237. doi: $10.2307 / 2570963$.

Lubis, A. N. et al. (2017). A study of service quality, corporate social responsibility, hospital image, and hospital value creation in medan.European Research Studies Journal, 20(4), pp. 125-133.

Magid, J. M., Cox, A. D. and Cox, D. S.
(2006). Quantifying brand image: Empirical evidence of trademark dilution.American Business Law Journal, 43(1), pp. 1-42. doi: 10.1111/j.1744-1714.2006.00010.x.

Morwitz, Vicki, Joel H. Steckel, and Alok Gupta. 2007. "When Do Purchase Intentions Predict Sales?" International Journal of Forecasting, 23(3): 347- 64 .

Notani, AS. 1998. Moderators of perceived behavioral control's predictiveness in the theory of planned behavior: A meta-analysis. Journal of Consumer Psychology, 7: 247-271.

Sharma, R. D. and Chahal, H. (1999). A Study of Patient Satisfaction in Outdoor Services of Private Health Care Facilities. Vikalpa, 24(4), pp. 69-76. doi:

10.1177/0256090919990409.

Sheeran, P. and Webb, T. L. (2016). The Intention - Behavior Gap The Intention - Behavior Gap.Social and Personality Psychology Compass, 10(9), pp. 503-518. doi: 10.1111/spc3.12265.

Sheikh, S. ur R. and Beise-Zee, R. (2011). Corporate social responsibility or cause-related marketing? The role of cause specificity of CSR.Journal of Consumer Marketing, 28(1), pp. 2739. doi: $10.1108 / 07363761111101921$.

Söderlund, M. and Öhman, N. (2005). 
Assessing behavior before it becomes behavior: An examination of the role of intentions as a link between satisfaction and repatronizing behavior.International Journal of Service Industry Management, 16(2), pp. 169-185. doi: 10.1108/09564230510592298.

Tang, W. (2007). Impact of Corporate Image and Corporate Reputation on Customer Loyalty : a Review.Management Science and Engineering, 1(2), pp. 57-62.

Vaaland, T. I., Heide, M. and Grønhaug, K. (2008). Corporate social responsibility: Investigating theory and research in the marketing context.European Journal of Marketing, 42(9-10), pp. 927-953. doi: 10.1108/03090560810891082.

Wilson, T. D., Lindsey, S. and Schooler, T. Y. (2000). A Model of Dual Attitudes.Psychological Review, 107(1), pp. 101-126. doi: 10.1037/0033-295X.107.1.101.

Yoon, E., Guffey, H. J. and Kijewski, V. (1993). The effects of information and company reputation on intentions to buy a business service.Journal of Business Research, 27(3), pp. 215-228. doi: 10.1016/0148-2963(93)90027-M. 